\title{
THE CHEMICAL WEAPONS CONVENTION: POLITICAL AND CONSTITUTIONAL ISSUES
}

\author{
Ronald D. Rotunda*
}

\section{INTRODUCTION}

While 160 nations have signed the Chemical Weapons Convention ("CWC"), only 75 countries have ratified it thus far. On April 25, 1997, after years of political maneuvers, the U.S. Senate finally added the United States to the list, after a vote that was considered too close to call until shortly before ratification. ${ }^{1}$ Although the final Senate vote was a lop-sided 74 to 26 , the period prior to ratification witnessed a great deal of jockeying, as liberal supporters of the treaty criticized their conservative opponents. ${ }^{2}$ This liberal support was a little surprising because there are important objections to the treaty based on the Fourth Amendment, which liberals, in other contexts, have supported.

Obviously the goal of the CWC-removing the terror of chemical weapons - is laudable, but its procedures raise important questions under the Bill of Rights, particularly under the Fourth Amendment, regulating searches and seizures, and the Fifth Amendment, guaranteeing no taking of property without just compensation. Some proponents of the CWC have responded to the constitutional argument by attacking the motives of those who raise these constitutional questions, accusing them of really being "glued to a 'we're No. 1' mentality."

* Albert E. Jenner, Jr. Professor of Law, University of Illinois, UrbanaChampaign. I thank Sandra Pulley, J.D., '99, the Stuart N. Greenberger Research Assistant of the University of Illinois.

1. What's News, Wall Street Journal A1 (April 25, 1997).

2. Thomas E. Ricks, Senate Approves Chemical-Arms Pact, Wall Street Journal A2 (Apr. 25, 1997).

3. See, e.g., Mary McGrory, A Lott of Gas, Washington Post Cl (Dec. 22, 1996), who repeats a refrain often found in the popular discussion of the CWC. She said: "Opponents, meanwhile, are glued to a 'we're No. 1' mentality: We should not be subject to unannounced, foreign inspection." Id. C2 . 
Whatever one thinks of the bona fides of those who criticize the $\mathrm{CWC}$, it is noteworthy that supporters of the CWC have urged Congress to enact legislation that would prohibit state and federal courts from enjoining CWC inspections even when those inspections and searches violate the Constitution. ${ }^{4}$ Surely, it is reasonable to be concerned about the constitutionality of the searches authorized by the $\mathrm{CWC}$, when its supporters concede the constitutional problem and try to work around it, not by amending the CWC, but by limiting the courts' jurisdiction to enforce the Constitution.

Before directly turning to the Constitutional questions, it is important to put the issue in perspective. It was not necessary for the United States to ratify the CWC in order to eliminate its stockpile of chemical weapons. We can eliminate our own stockpile unilaterally. (In fact, we already have decided to

4. E.g., Barry Kellman and Edward Tanzman, Implementing the Chemical Weapons Convention: Legal lssues (Lawyers Alliance for World Security, Committee for National Security, July, 1994) at 16:

"While judicial interference with the CWC is unlikely because of national security and foreign affairs implication, a legislative ban on injunctions against $C W C$ inspections would eliminate this risk entirely. Instead of seeking an injunction, the subject of the inspection should be permitted to seek monetary damages as compensation for any losses resulting from an unconstitutional search." [emphasis added.]

Limiting the jurisdiction of federal courts so that they cannot enjoin violations of the Fourth Amendment is unconstitutional. If a search is unconstitutional, Congress cannot avoid that problem by limiting the courts' jurisdiction to rule on that claim. See Ronald D. Rotunda, Congressional Power to Restrict the Jurisdiction of the Lower Federal Courts and the Problem of School Busing, 64 Georgetown L.J. 839 (1976). See also 1 Ronald D. Rotunda and John E. Nowak, Treatise on Constitutional Law: Substance and Procedure \$\$ 2.10, 2.11 (West Publishing, 2d ed. 1992).

The Clinton Administration has argued that it can bypass the warrant clause for national security purposes. See R. Jeffrey Smith, Administration Backing No-Warrant Spy Searches, Washington Post A19 (July 15, 1994), quoting Deputy Attorney General Jamie S. Gorelick, who claimed that the President "has inherent authority to conduct warrantless searches for foreign intelligence purposes." Id. Of course, President Clinton is not the only President to make such claims. President Nixon asserted similar powers. Richard Gid Powers, Secrecy and Power 439-85 (Free Press, 1987).

5. Kellman and Tanzman, Implementing the Chemical Weapons Convention (cited in note 4) argue that Congress should authorize a damage remedy; they argue that the Government should specifically consent to suit under the Federal Torts Claims Act, 28 U.S.C.A. $\$ \$ 136$ (b), 2680 , so that it is clear that "a victim of an unconstitutional search can receive damages, during unconstitutional arms control verification activities...." Kellman and Tanzman, Implementing the Chemical Weapons Convention at 18 (cited in note 4) (emphasis added).

However, violations of the Fourth Amendment, like violations of the First Amendment's free speech guarantee, cannot be "cured" by a damage remedy. If damages were an effective remedy, there would be no need for an exclusionary rule. As discussed below, the Fifth Amendment clause prohibiting the taking of property "without just compensation" is the only clause where money damages provide a cure. 
eliminate our chemical arms by 2004 , prior to the time we would have to eliminate them under the treaty.)

Similarly, the ratification of the CWC does not prevent the United States from renouncing the use of chemical weapons. In the past, the United States has threatened to use chemical weapons only in retaliation-if other countries used those weapons first. We can, if we wish, unilaterally forgo any chemical retaliatory option. Again, the $\mathrm{CWC}$ has nothing to do with that issue.

The dispute involving the CWC focuses, instead, on different questions. Is the manufacture and storage of chemical weapons verifiable-particularly when the manufacturer is a private person, and the storage facility is some terrorist's garage? Are the intrusive search mechanisms of this treaty constitutional? If this particular treaty, even with its intrusive searches, still allows too many loopholes that impinge on verification, does that affect the analysis of the Fourth Amendment? Is it proper for the United States to authorize inspectors (who will be searching for evidence of a crime $e^{6}$ ) to engage in extensive and highly intrusive searches without any requirement or procedure for the inspectors to seek a search warrant? Normally, we expect criminal search warrants to describe with particularity the places to be searched and the things to be seized. Moreover, they may be issued only after a neutral judicial officer finds probable cause. But the CWC and its implementing legislation provide for none of that.? ${ }^{7}$ Under these circumstances, is this treaty constitutional and will it work?

6. Convention on the Prohibition of the Development, Production, Stockpiling and Use of Chemical Weapons and on Their Destruction, Jan. 13, 1993, S. Treaty Doc. No. 21, 103d Cong., 1st Sess. (1993), Art. VII, 9 I 1(a), (b), and (c), reprinted in 32 I.L.M. 800 (1993) (“CWC").

These provisions make clear that if the United States ratifies the CWC, it agrees to "[p]rohibit natural and legal persons" within its jurisdiction from "undertaking any activity prohibited to a State Party under this Convention, including enacting penal legislation with respect to such activity." CWC, Art. VII, q1(a) (emphasis added).

Further, the United States will obligate itself to "[e]xtend its penal legislation enacted under subparagraph (a) to any activity prohibited to a State Party under this Convention undertaken anywhere by natural persons, possessing its nationality, in conformity with international law." CWC, Art. VII, I 1(c) (emphasis added). Note that this subparagraph requires that the penal legislation conform to international law. There is no requirement that the legislation must conform to our Constitution. It is not a defense, under this subparagraph, that the United States refuses to enact penal legislation on the grounds that it violates our Constitution.

7. Initially, the proposed Chemical Weapons Implementation Act-which will ensure observance of the requirements of the CWC-provides for the use of search warrants, and for warrantless search warrants in exigent circumstances. See S. 495, 105th Cong., 1st Sess. (1997), proposed Title I, $\$ \S 229 \mathrm{~A}(\mathrm{a})(1),(2)$, in 143 Cong. Rec. S2660 


\section{LIMITATIONS OF THE CHEMICAL WEAPONS CONVENTION}

\section{A. INTRODUCTION}

Proponents of the CWC typically claim that American ratification is essential because it is our last great chance to outlaw chemical warfare. For all its defects, supporters say that it is better than nothing, and that its benefits justify limiting and narrowly applying the Fourth Amendment. ${ }^{8}$ Opponents express concern that the Chemical Weapons Convention-although it authorizes very intrusive searches without warrants and without probable cause - is like a generous legacy in a pauper's will, which promises much but delivers little, because of its significant loopholes.

The question of whether the CWC accompanies intrusive searches with significant loopholes has a Fourth Amendment dimension, because, as discussed below, the Court is more likely to invalidate a statutory ${ }^{10}$ system of searches that is not welldesigned and narrowly tailored to ferret out wrongdoing. ${ }^{11}$ A defective CWC that is not carefully drafted and promises more than it can deliver is more likely to be invalid under the Fourth Amendment. If the CWC has both intrusive searches and significant loopholes, then it is much worse than a generous legacy in a pauper's will, for it intrudes on important constitutional rights without fulfilling its promise of eliminating chemical warfare.

Let us now turn to some of the political issues that affect the question whether the CWC is verifiable and consider if these

(daily ed., March 20, 1997). See generally 3 Ronald D. Rotunda and John E. Nowak, Treatise on Constitutional Law $\$ \S 18.30$ (b) (cited in note 4) (discussing some emerging issues involving the right to privacy).

8. See, e.g., Thomas A. Connolly, Does the Constitution Limit On-Site Inspection?, Arms Control Today 8 (July, 1988). See also Edward L. Rowny, Yes to the Chemical Weapons Accord, Washington Post A21 (April 23, 1997), supporting the CWC as better than nothing and stating: "However, I must emphasize that we should not be overly optimistic about the effectiveness of the CWC"; David Kay, et al., First the Treaty, Then the Hard Work, Washington Post C7 (April 13, 1997), stating: "A perfect solution? No. But clearly it is better than the available alternatives."

9. Cf. Edwards v. California, 314 U.S. 160, 186 (1941) (Jackson, J., concurring): "a promise to the ear to be broken to the hope, a teasing illusion like a munificent bequest in a pauper's will."

10. The CWC is not a self-executing treaty and Congress will have to enact a statutory scheme to implement it.

11. Chandler v. Miller, 117 S. Ct. 1295 (1997), discussed in Part II.D. at 137-39. 
political issues may influence the resolution of the constitutional questions.

\section{B. NON-SIGNATORIES}

One inherent limitation of the CWC is that outlaw countries can simply refuse to ratify it. The threat posed to the United States by chemical weapons is less likely to come from countries like Sweden, than from pariah states like Libya, Syria, North Korea, and Iraq-none of which have ever signed the treaty, let alone ratified it. Moreover, we should also expect that some foreign countries that do sign the CWC will evade it by moving their chemical weapons facilities to non-signatory countries. $^{\text {. For example, the Central Intelligence Agency has }}$ acknowledged that: "Some other republics [of the former Soviet Union] maintain that Russia still has chemical weapons materials in their territories." ${ }^{13}$

\section{The CWC's Limited BAN OF Chemical Weapons}

Countries that do ratify the $\mathrm{CWC}$ can also avoid violation or detection by redirecting their chemical efforts. Given the nature of chemical weapons, many chemicals have multiple uses, only one of which would be illegal under the treaty. There is no way to avoid this problem because chemicals necessary to produce mustard gas are also needed to produce ink for pens. ${ }^{14}$ Chlorine was used in World War I in chemical warfare, though today we use it legally for laundry. ${ }^{15}$ The Nazi gas chambers relied on legal rodenticides, and many legal dyes, drugs, additives, and pesticides can become chemical weapons by minor changes in their processing. ${ }^{16}$ Ordinary chemicals can be put to extraordinary, and lethal, use.

12. E.g., Mark Yost, China's Deadly Trade in the Mideast, Wall Street Journal A18 (Dec. 4, 1996), reporting that U.S. intelligence sources, relying on documents seized from Germans involved with illegal weapons sales, are concerned that China may be involved in supplying equipment for an underground chemical weapons factory in Syria. China has also been a supplier to Mideast countries such as Iran and Iraq.

13. See Letter of August 27, 1993, from Admiral William O. Studeman (then Acting Director of the CIA) to Senator John Glenn (on file with the author).

14. Even supporters of the CWC concede this point. E.g., Mary McGrory, A Lott of Gas C2 (cited in note 3).

15. Ian V. Hogg, Gas 24 (Ballantine Books, 1975).

16. E.g., John Adams, The Chemical Weapons Convention: Legal and Juridical $O b$ servations, 1 International and Security Law News 3 (Fall, 1996) <http://www.homesites. com/fed-soc/in010104.htm>. 
We should also expect that other countries will develop more advanced chemical weapons that work around the restrictions of the CWC and exploit its limitations. The intelligence community recently reported that Russia is developing and producing a new generation of chemical weapons that are not covered by the CWC's Schedule of Chemicals. ${ }^{17}$ Just as restrictive tax laws spawn more creative tax shelters, the CWC should be expected to beget different types of chemical weapons. The CWC will likely channel (rather than ban) chemical weapons development into types that may be more insidious, more dangerous, and less detectable.

These new Russian nerve gases, such as A-232, are made from common industrial and agricultural chemicals. Two relatively harmless compounds are stored in separate containers. Because they are not lethal until mixed, they are easier to manufacture than conventional nerve gas, more difficult to detect, and safer to transport and stockpile, until they are mixed together, when they then become deadly. Even microscopic amounts of A-232 can kill. This type of chemical weapon was expressly designed to be outside of the CWC ban. If Russia were to ratify the CWC, production of these types of chemical weapons (called Novichok "binary" weapons) could continue. ${ }^{18}$ The CWC does not affect weapons designed to circumvent its verification regime.

A veteran Soviet chemical weapons specialist, who confirmed the development of these binary weapons (and was jailed for his whistle-blowing), has reported:

Our generals see the implementation of the [CWC] treaty with its loopholes as a way to dispose of their obsolete and hazardous stockpiles with American taxpayer's help, while preserving their new classes of toxins and, even worse, permitting their sale abroad for hard currency. ${ }^{19}$

\section{OTHER LOOPHOLES}

The CWC claims that it will eliminate all chemical weapons and will effectively ban their use, development, production, de-

17. Bill Gertz, Russia Dodges Chemical Arms Ban: New Nerve Agent Hard to Uncover, Washington Times A1 (Feb. 4, 1997), available at 1997 WL 3662854.

18. J. Michael Waller, The Chemical Weapons Coverup, Wall Street Journal A18 (Feb. 13, 1997).

19. Vil Mirzayanov, Free to Develop Chemical Weapons, Wall Street Journal A16 (May 25, 1994), available at 1994 WL 333375. Mr. Mirzayanov was jailed in 1992 and in 1994 for revealing Moscow's continuation of covert chemical weapons production. 
ployment, and stockpiling. ${ }^{20}$ When something sounds too good to be true, it usually is. Consider an unremarkable chemical implement of war, riot control chemicals, and what the CWC says about them. The CWC signatories solemnly agree that -

Each State Party undertakes not to use riot control agents as a method of warfare. ${ }^{21}$

"Chemical Weapons" are defined as including-"Toxic chemicals and their precursors, except where intended for purposes not prohibited under this Convention ...."22

This definition does not seem noteworthy, until one moves to another section of the CWC, where we learn that what the right hand giveth, the left hand taketh away, for the CWC tells us that the phrase, "Purposes Not Prohibited Under this Convention," means, among other things: "Law enforcement including domestic riot control purposes."

In short, countries may develop, test, stockpile, and use riot control chemicals, as long as they purport to use them domestically. The CWC does not ban riot control chemicals; instead, it appears to authorize countries to use against their own civilians what they may not use against enemy troops in time of war. ${ }^{24}$ Moreover, if these riot control weapons are used against enemy troops, we may never know for sure. Even today, not all authorities agree on the extent to which there was the use of chemical weapons by the North Vietnamese during the Vietnam War, and by the Iraqis during the Gulf War. ${ }^{25}$

20. CWC, Preamble, 6th 9 [unnumbered] (cited in note 6), states that its goal is: "to exclude completely the possibility of the use of chemical weapons." A related (and somewhat inconsistent) goal is: "to promote free trade in chemicals..." Id. at 9th I [unnumbered].

21. CWC, Art. I, 95 (cited in note 6).

22. CWC, Art. II, 9 1(a) (cited in note 6).

23. CWC, Art. II, I 9(d) (cited in note 6) (emphasis added).

24. President Clinton has announced that he interprets the CWC to forbid the United States from using riot control agents "even for humanitarian purposes in situations where combatants and noncombatants are intermingled, such as the rescue of downed air crews, passengers and escaping prisoners and situations where civilians are being used to mask or screen attacks." Statement of June 23, 1994, quoted in Letter of Senator Jesse Helms to National Security Advisor Sandy Berger, Feb. 13, 1997 at 6 (on file with author). So foreign countries can continue to manufacture and store riot control agents, while the United States will be forbidden to use these agents when they are the most humane way of rescuing downed air crews. He is interpreting the CWC more strictly than the military has been interpreting it, and more strictly than the drafters interpreted it. Id.

25. See, e.g., Dana Priest, CIA Analysts of Iraqi Chemical Weapons in Gulf Interviewed Only Last Month, Washington Post A18 (April 16, 1997). 
Another particularly significant loophole is found in a portion of the CWC that authorizes the inspection team to examine vehicular traffic exiting the inspection site, ${ }^{26}$ but excludes from this inspection all "personal passenger vehicles exiting the site...." Chemical weapons are not like armored tanks. Chemical weapons can be easily hidden in the trunk of any passenger car. Sometimes only drops of a chemical are needed to cause many deaths. The CWC provision exempting passenger trunks only guarantees that those who wish to transport chemical weapons right under the noses of the CWC inspectors will use the trunks of their passenger cars rather than pickup trucks.

Of course, the fact that the CWC will not be entirely effective is not, by itself, an argument against it. The best should not be an enemy of the good. However, ratification of the CWC may lull our vigilance and undercut future efforts to develop a Convention that works. The CWC, in that case, would undercut rather that promote the reduction of chemical weapons.

More importantly, loopholes like these in the CWC affect the analysis of the Fourth Amendment. Consider Chandler $v$. Miller, ${ }^{28}$ where the Court invalidated a Georgia law that required candidates for certain state offices to certify that they had tested negative for illegal drug use within 30 days prior to qualifying for nomination. The Court ( 8 to 1 ) found that the statute was unconstitutional because it was an unreasonable "suspicionless" search prohibited by the Fourth Amendment. In the course of its analysis of the problem, the Court found that an important reason the Georgia law was invalid under the Fourth Amendment is that -

Georgia's certification requirement is not well designed to identify candidates who violate antidrug laws. Nor is the scheme a credible means to deter illicit drug users from seeking election to state office. The test date - to be scheduled by the candidate anytime within 30 days prior to qualifying for a place on the ballot-is no secret.... [U]sers of illegal drugs, save for those prohibitively addicted, could abstain for a pretest period sufficient to avoid detection. ${ }^{29}$

26. CWC, Verification Annex, Part X (Challenge Inspections), 19 29, 30 (cited in note 6). 6).

27. CWC, Verification Annex, Part X (Challenge Inspections), 130 (cited in note

28. 117 S. Ct. 1295 (1997).

29. $117 \mathrm{~S}$. Ct. at 1303-04 (emphasis added). 
A similar analysis applies to the CWC. A treaty that provides for suspiciousless searches of factories and trucks leaving the factory but not the trunks of cars leaving these factories is, like the law invalidated in Chandler, a treaty that "is not well designed to identify [people] who violate [chemical weapons] laws." Nor does the CWC offer "a credible means to deter illicit" production and storage of chemical weapons.

\section{E. FAILURE OF WILL}

In order for the CWC to work, it must be enforced. We would expect that the United States will be willing to enforce the treaty within our own borders. If we find a terrorist group clandestinely storing chemical weapons, we would take action. But will the United States or other nations be willing to take action against a state that is found to have violated the treaty? There have been disquieting reports that the international community, including the United States, is not enforcing the blockade against Iraq. ${ }^{30}$ If nations, including the United States, will not vigorously enforce sanctions against Iraq, imposed after it was defeated in a war, will they enforce the CWC? This failure of will, while troubling, is more of a political than a constitutional issue and probably does not affect the Fourth Amendment analysis under cases like Chandler.

\section{F. INABILITY TO VERIFY}

Perhaps no Convention, no matter how intrusive its search mechanisms, can stop a small number of individuals from creating or storing chemical weapons. U.S. military experts have testified that it is a fruitless exercise to stamp out these easily concealable weapons. As CIA Director R. James Woolsey said in 1994: "The chemical-weapons problem is so difficult from an intelligence perspective that I cannot state that we have high confidence in our ability to detect noncompliance, especially on a small scale." ${ }^{31}$ Others have echoed this view. ${ }^{32}$ Neophytes should not jump in where experts fear to tread.

30. Mark Yost, Iran Helps Iraq Beat Oil Embargo; Will U.S. Respond?, Wall Street Journal A18 (Feb. 13, 1997). Vice Admiral Thomas B. Fargo announced that there is solid evidence that Iran is helping Iraq smuggle oil, but "[s]everal Navy officers said that they had been told not to scrutinize Iranian-flagged vessels closely, even in international waters." Id.

31. J. Michael Waller, The Chemical Weapons Coverup, A18 (cited in note 18). Similarly, a National Intelligence Estimate, in May of 1995, concluded that production of new chemical weapons "would be difficult to detect and confirm as a CWC-sponsored activity." Id. 
Our experience thus far should cause us to be modest in estimating our ability to ferret out chemical weapons production and storage. Consider the U.N. experience with Iraq. The current inspection of Iraq (defeated in the Persian Gulf War) by the United Nations Special Commission ("UNSCOM") is the most intrusive, systematic, and rigorous inspection in modern times. UNSCOM has had unprecedented access to Iraq for years. Yet the United Nations did not uncover significant information about Iraq's chemical weapons capability from its onsite inspectors. Rather, it uncovered this information because of a defector. ${ }^{33}$ Intrusive as the CWC is, it will not be as intrusive as the inspection of a defeated nation by the victors in war. Yet, Iraq was able to conceal this significant information from U.N. inspectors, until the defection of a key soldier.

The inability to verify, like the treaty loopholes, is not just a political issue but a constitutional one under cases like Chandler. Recall that the Court there said that one reason the Georgia law must be invalidated is that the Georgia scheme is not "a credible means to deter illicit drug users from seeking election to state office," because it was easily evaded. ${ }^{34}$

If the problem with the CWC were merely its inability to verify violations, it would merely be useless, like a magnificent legacy in a pauper's will. But the CWC is much worse if it also compromises our constitutional guarantees. Then, unlike an empty legacy, it will cause actual harm. The average American business or a typical individual-neither of whom are in the business of manufacturing poison gas - will be subject to extensive and intrusive inspections, that may violate the Fourth Amendment and the Fifth Amendment. To those issues we now turn.

32. For example, then Vice President Bush said that "plants for producing chemical weapons are difficult to distinguish from plants producing chemicals for industry and, in fact, some chemicals with peaceful utility are structurally similar to some chemicals that are used in warfare. So verification is particularly difficult with chemical weapons." Speech by Vice President George Bush, Conference on Disarmament: Chemical Weapons Convention, April 18, 1984, reprinted in U.S. Arms Control and Disarmament Agency, Documents on Disarmament 299, 300 (1984).

33. Hussein Kamel's defection prompted Baghdad to turn over 100 boxes of information about its chemical and biological weapons' program. The U.N. did not know about this information, and it never would have come to light had there been no defection. See Daniel Williams, Iraqi Defectors Killed On Return to Baghdad; Relatives Reportedly Shot Brothers, Washington Post A1, A18 (Feb. 24, 1996); Greg Myre, After 5 Years in Iraq, Work Is Still Turbulent for U.N. Arms Inspectors, Washington Post A16 (April 9, 1996).

34. 117 S. Ct. at 1304. 


\section{CONSTITUTIONAL PROBLEMS}

\section{A. INTRODUCTION}

Does the proposed Convention violate constitutional guarantees? In particular, let us focus on two constitutional issues the Search and Seizure Clause of the Fourth Amendment and the Just Compensation Clause of the Fifth Amendment.

First, if the intrusive searches result in loss of intellectual property, will just compensation be provided? Even supporters of the CWC acknowledge that it may facilitate or enable foreign governments or inspectors from those governments to engage in industrial espionage, the theft of trade secrets, and the taking of other types of intellectual property. ${ }^{35}$ The CWC itself offers no just compensation for those whose property has been literally "taken."

Second, do the inspection mechanisms that the Convention envisions violate the Fourth Amendment protection against unreasonable searches and seizures? The CWC contemplates extremely intrusive searches of private property. The CWC search of private property must be unusually thorough to have any chance of working effectively, but such invasive searches create a greater risk of a violation of the Fourth Amendment. Numerous businesses or persons will be subject to these searches. Because of the multiple uses of chemicals and the ease with which many chemical weapons can be created or stored, we may expect searches of over ten thousand U.S. businesses (perhaps 50,000 industrial facilities or more), that might use, produce, or

35. E.g., Barry Kellman, et al., Disarmament and Disclosure: How Arms Control Verification Can Proceed Without Threatening Confidential Business Information, 36 Harv. Intl. L.J. 71, 101 (1995).

36. The Chemical Manufacturers Association has supported a global ban on the manufacture and stockpiling of chemical weapons. Yet it has also expressed concern for the "loss of proprietary information," because of the work of the international agency that the CWC creates. The loss of trade secrets can amount to a "multimillion dollar price tag." It "can cripple even a giant company and can be fatal to a smaller enterprise." The U.S. Chemical Industry Can Live With a Chemical Weapons Convention, Arms Control Today 21 (Nov., 1989). See also Burrus M. Carnahan, Chemical Arms Control, Trade Secrets, and the Constitution: Facing the Unresolved Issues, 25 Intl Lawyer 167, 170-71 (1991).

This last point ("fatal to a smaller enterprise") is quite significant. The burdens of the CWC fall disproportionately on smaller companies. Companies will also have costs associated with inspections. Larger businesses, those who typically have various government contracts, will pass along the expenses to the U.S. Government. Also, for large businesses, the extra costs are marginal. For smaller businesses, the costs may be proportionally greater, and they are less likely to have the luxury of passing on the costs to the Government. 
store chemicals. ${ }^{37}$ Any soap factory or ink pen factory can produce or store chemical weapons.

However, CWC searches are not limited to places of business. Private homes are also subject to CWC inspections. ${ }^{38}$ One's garage or bedroom can be the storage place for chemical weapons, or the place of their manufacture. Japan (which is not limited by our Fourth Amendment) was unable to prevent a religious cult from producing and using sarin in its poison gas attack in the Tokyo subways. The cult made these chemical weapons in a small, undistinguished room - not a high-tech lab.

As General William Burns (then head of the U.S. Arms Control and Disarmament Agency) has said, "chemical weapons can be manufactured in almost anyone's garage, as long as you have a little high school chemistry behind you." ${ }^{39}$ If even extremely intrusive mechanisms will not be truly effective (and the evidence suggests that they will not), then one wonders if all of this is worth the candle.

\section{B. ApPlicability Of The U.S. Constitution}

It should cause no shock that the U.S. Constitution applies in foreign affairs, and that a treaty or executive agreement that conflicts with the Constitution is unconstitutional. Surprisingly, however, some commentators have occasionally argued, even in recent times, that the foreign affairs power or so-called national security powers limit the application of the Constitution. For example, during the oral argument in Dames \& Moore $v$. Regan, ${ }^{40}$ which upheld the Iranian Hostage Executive Agreement, a lawyer supporting the Agreement argued that the United States must release Iranian assets simply because the Executive Agreement said so. Justice Rehnquist asked: "What if the agreement had said no one in the U.S. should criticize the

37. E.g., Adams, The Chemical Weapons Convention: Legal and Juridical Observations at 10 (cited in note 16) (over 10,000 sites); Carnahan, 25 Intl. Law at 180 (cited in note 36$)(50,000$ sites "might reasonably be subject to challenge inspection.") (footnote omitted).

38. CWC, Art. IX, I (cited in note 6). See also, Kellman, et al., 36 Harv. Intl. L.J. at 92 (cited in note 35 ). 1989).

39. Eric Hamburg, Constitution vs. Arms Control, New York Times A19 (Dec. 18,

40. 453 U.S. 654 (1981). 
Ayatollah? Would the U.S. be liable?" The lawyer said yes! ${ }^{41}$ The Court, fortunately, rejected that argument. ${ }^{42}$

Justice Black, in Reid v. Covert, ${ }^{43}$ articulated what is the generally accepted view today among commentators and courts:

The United States is entirely a creature of the Constitution. Its power and authority have no other source. It can only act in accordance with all the limitations imposed by the Constitution.... The concept that the Bill of Rights and other constitutional protections against arbitrary government are inoperative when they become inconvenient or when expediency dictates otherwise is a very dangerous doctrine and if allowed to flourish would destroy the benefit of a written Constitution and undermine the basis of our government. ... [N] o agreement with a foreign nation can confer power on the Congress, or on any other branch of Government, which is free from the restraints of the Constitution. ${ }^{44}$

In short, if the United States could not constitutionally search a factory, or a storage area, or a garage without a search warrant or probable cause, then it cannot constitutionally authorize foreign inspectors to engage in such searches. The United States cannot delegate to foreign officials a power that it does not possess. Searches that violate the Fourth Amendment are not cured of the violation by the simple expediency of a treaty ratification or an executive agreement. ${ }^{45}$

Sometimes people argue that Congress should leave to the courts the responsibility of sorting out these constitutional arguments. ${ }^{46}$ It is certainly true that the courts are the ultimate safeguard of our liberty, but that ultimate safeguard should not be used as an excuse for an earlier violation. The courts, when reviewing the constitutionality of legislation, typically presume

41. See Ronald D. Rotunda, Modern Constitutional Law: Cases and Notes 256 (West Publishing, 5th ed. 1997).

42. See John E. Nowak and Ronald D. Rotunda, A Comment on the Creation and Resolution of a "Nonproblem": Dames \& Moore v. Regan, the Foreign Affairs Power, and the Role of the Court, 29 U.C.L.A. L. Rev. 1129 (1982).

43. 354 U.S. 1 (1957) (plurality opinion). No other Justice disagreed with Justice Black's statement. The contrary view derives from some dictum, taken out of context, by Justice Holmes in Missouri v. Holland, 252 U.S. 416 (1920).

44. 354 U.S. at 5-6, 14, 16 (Black, J., joined by Warren, C.J., Douglas, J., and Brennan, J.) (plurality opinion) (footnotes omitted; emphasis added).

45. This issue is discussed in detail in 1 Rotunda and Nowak, Treatise on Constitutional Law: Substance and Procedure $\$ 6.5$ (cited in note 4).

46. For example, President Franklin D. Roosevelt, in urging a Congressman to support a bill in 1935, said: "I hope your committee will not permit doubts as to constitutionality, however reasonable, to block the suggested legislation." Quoted in Rotunda, Modern Constitutional Law: Cases and Notes at 11 (cited in note 41). 
that it is constitutional. That presumption assumes that Congress has exercised its independent judgment. Congress should not abdicate its constitutional duty when enacting legislation that implements the $\mathrm{CWC}$. $^{47}$

\section{ApPlication Of CWC To PRIVATE INDIVIDUALS}

In evaluating the constitutional arguments, it is important to realize that the CWC is unlike many treaties, which usually apply only to governments. The CWC not only bans foreign countries from manufacturing, developing, and storing certain chemical weapons, ${ }^{48}$ it also directly applies the same restrictions to private individuals and companies. ${ }^{29}$ The countries ratifying the CWC must allow international inspectors to engage in "systematic verification through on-site inspection and monitoring with on-site instruments" of publicly or privately owned places where targeted chemical weapons might be produced, stored, etc. ${ }^{\text {so }}$

\section{JUST COMPENSATION}

The Constitution provides that no private property shall "be taken for public use, without just compensation." "I1 Intellectual property is a form of property. ${ }^{52}$ If the federal government simply takes this property, the Constitution requires that it pay just compensation. If the federal government instead sets up a legal structure that authorizes international inspectors to engage in intrusive inspections that allow them to make off with intellectual property, there is also a "taking" for purposes of the just compensation clause. ${ }^{53}$ Even CWC supporters have conceded that the "procedures likely to be applied to verify arms control

47. When a House Member argued that it would be "officious" to debate the constitutionality, Madison responded that "it is incontrovertibly of as much importance of this branch of Government as to any other, that the constitution be preserved entire. It is our duty." 1 Annals of Congress 500 (1789) (emphasis added). That is why the Court gives Congress "the presumption of validity its enactments now enjoy." City of Boerne v. Flores, 117 S. Ct. 2157,2172 (1997).

48. Subject to its various exceptions, definitions, etc.

49. The CWC makes clear that "the detailed procedures for its implementation shall apply to all chemical weapons owned or possessed by a State Party, or that are located in any place under its jurisdiction or control...." CWC, Art. IV, $q 1$ (cited in note 6) (emphasis added).

50. CWC, Art. IV, 3 (cited in note 6).

51. U.S. Const., Amend. 5.

52. E.g., 2 Rotunda and Nowak, Treatise on Constitutional Law: Substance and Procedure $\$ 17.5$ (cited in note 4) (discussing various types of property).

53. "Whenever property is taken from someone with the assistance of government officers, there is a deprivation of property." Id. at $\$ 17.5$ (b) (citing cases). 
treaties are sufficiently intrusive to pose a legitimate threat to" confidential business information. $^{\text {s4 }}$

Now that the CWC is ratified, the United States must enact laws that will implement the CWC's extensive inspection requirements backed by penal legislation that would apply to all natural or legal persons within the jurisdiction of the United States and all U.S. citizens abroad. ${ }^{55}$ The intrusive inspections create a serious risk of industrial espionage by foreign inspectors, many of whom come from cultures that do not respect intellectual property rights. ${ }^{56}$ If, in the course of CWC inspections, trade secrets or other forms of intellectual property are stolen because of the CWC's intrusive searches, there will be a taking of property, for which the Fifth Amendment guarantees just compensation. $^{57}$

The CWC candidly acknowledges and concedes that there is a risk of loss of trade secrets and other forms of intellectual property. The organization that the CWC creates is supposed to take "every precaution" to protect the civil and military secrets of which it becomes aware. ${ }^{8}$ This promise however, is vaguely worded, does not explain exactly what will be done, and provides no mechanism for just compensation if intellectual property is stolen. If foreign inspectors abuse their position and steal intellectual property, then the only realistic remedy is for the United States to pay just compensation to those people who have suffered damages.

The CWC allows each ratifying state to request an on-site inspection "of any facility or location in the territory or in any other place under the jurisdiction or control of any other State Party" in order to resolve any questions regarding noncompliance." The inspected State Party has the "obligation to provide

54. Kellman, et al., 36 Harv. Intl. L.J. at 125 (cited in note 35) (the authors note that, even with careful preventive measures, there will be loss of this information so that the government should explore various means of providing just compensation).

55. CWC, Art. VII, I 1(c) (cited in note 6). The countries ratifying the CWC are also obligated to enact legislation criminalizing an individual's production of targeted chemicals.

56. These intrusive searches of private property, conducted without a warrant, also raise problems under the Fourth Amendment, which will be discussed later.

57. See Dow Chemical Co. v. United States, 476 U.S. 227, 232 (1986) (Dow Chemical could raise Fifth Amendment "taking" claim if one who searches would use the confidential information obtained to compete with Dow); Ruckelshaus v. Monsanto, 467 U.S. 986, 1003-04 (1984) (trade secrets are property protected by the just compensation clause).

58. CWC, Art. VIII, 15 (cited in note 6).

59. CWC, Art. IX, I 8 (cited in note 6). 
access," ${ }^{, 60}$ and the right to "prevent disclosure of confidential information and data, not related to this Convention." tion acknowledges that intellectual property may be compromised, but limits the right to protect intellectual property to information "not related to this Convention."

Given the nature of chemicals that can be used for dual purposes (one legal, one illegal), virtually all relevant intellectual property will be "related to this Convention." Rather than protecting intellectual property, the CWC recognizes that intellectual property can be compromised, but then limits the right of the United States to protect the theft of the intellectual property of its citizens. This provision appears to give U.S. citizens a mere right to argue that the information is not related to the Convention. Rather than protecting property, the CWC may only give victims an opportunity to complain.

If the United States subsequently suspects that a particular foreign inspector is likely to steal trade secrets or to compromise any intellectual property during a certain inspection, the CWC sets up a rather complex procedure to follow. When the initial list of inspectors is presented, a country can declare which inspectors it does not accept. ${ }^{62}$ But once a State Party has been notified of an inspection it "shall not seek to have removed from the inspection team for that inspection any of the designated inspectors or inspection assistants named in the inspection team list.. ${ }^{, 63}$ In addition, if the Director-General of the CWC believes that a country's non-acceptance "impedes the designation of a sufficient number of inspectors or inspection assistants or otherwise hampers the effective fulfilment of the tasks of the Technical Secretariat," then the Director-General must refer the issue to the Executive Council. ${ }^{64}$

In short, the United States will have the ability to make initial objections, but these can be overruled by the Executive Council. If the United States makes objections, some other countries will make counter objections, in a tit-for-tat response, just as some countries expel one of our diplomats in reaction to our expelling one of theirs. The right to make objections (which can be overruled and met with similar objections by other coun-

60. CWC, Art. IX, I 11(b) (cited in note 6).

61. CWC, Art. IX, 911 (c) (cited in note 6) (emphasis added).

62. CWC, Verification Annex, Part II, 92 (cited in note 6).

63. CWC, Verification Annex, Part II, 95 (cited in note 6).

64. CWC, Verification Annex, Part II, 17 (cited in note 6) (emphasis added). 
tries) may only provide a thin veneer of protection of American interests.

While the CWC does not set up a just compensation scheme, it does recognize that property, including intellectual property, may be improperly taken. The Fifth Amendment's just compensation clause does not forbid the taking of property. The government can take property, if it pays just compensation. In that sense, the just compensation clause is different from other rights protected by the Bill of Rights, violations of which cannot be cured simply by paying compensation. For example, if the government prevents a citizen from exercising free speech, the government has violated the First Amendment. The affected citizen may always sue the government for damages, but payment of the damages does not "cure" the original violation.

If there is a theft of intellectual property because of the CWC searches, the U.S. Government can "cure" this taking of property by providing for just compensation. But first it must establish a procedure to provide just compensation. The Government has not yet done so, and theories of compensation under present law are unclear at best. ${ }^{65}$ Now that the United States has ratified the CWC, it should turn its attention to creating a fair, prompt, and reasonable procedure for just compensation.

This new just compensation law will have to deal with some difficult procedural issues. For example, if an American claims that an inspector stole his or her trade secrets, will the American be able to subpoena the foreign inspector? If the foreign inspector refuses to submit to a deposition and discovery of relevant materials, who will bear the cost of that refusal? Will the burden of proof shift if the foreign inspector ignores an American subpoena? Implementing legislation should provide that the United States Government would bear the cost, because it is the United States Government that has authorized the inspector to enter the country, to inspect the premises, and then to leave the jurisdiction of the United States and its courts.

This new law will also have to determine how to measure the value of the property that has been taken. The typical rule, as Justice Oliver Wendell Holmes announced, is that amount

65. See Carnahan, 25 Intl. Law at 173-77 (cited in note 36). 
due is measured by "What has the owner lost? not, What has the taker gained."

There is an additional issue regarding just compensation. As discussed in the next section, Fourth Amendment violations cannot be "cured" merely by the payment of compensation. If an action violates both the Fourth and the Fifth Amendment, the remedies for the two violations are independent. The person whose Fourth Amendment rights are violated will also have a Fifth Amendment right to compensation if there has been an unlawful physical intrusion of his premises. ${ }^{67}$

If the law limits the right of the owner of property to exclude others from areas that the property owner did not open to the general public (which is exactly what the CWC does, by granting a right of entrance to the inspectors, a right that is permanent as long as the CWC is in force), there is a taking for which compensation is due. ${ }^{68}$ As Justice Thurgood Marshall has noted: "The power to exclude has traditionally been considered one of the most treasured strands in an owner's bundle of property rights." ${ }^{169}$

Even if the degree of intrusion is quite minor, compensation is still due. Consider, for example, Loretto $v$. Teleprompter Manhattan CATV Corp. ${ }^{70}$ A city ordinance required an owner of a rental building to allow installation of a cable television receiver on the outside of the landlord's apartment building (portions of her roof and the side of her building). The ordinance tried to avoid the takings issue by paying a one-time $\$ 1$ fee. Justice Marshall, for the majority, rejected the city's argument and held that there was a taking, for which just compensation was due, even if the amount of the physical intrusion is no "bigger than a breadbox." "11

66. Boston Chamber of Commerce v. Boston, 217 U.S. 189, 195 (1910). See also 2 Rotunda and Nowak, Treatise on Constitutional Law: Substance and Procedure $\$ 15.14$ (cited in note 4).

67. Physical occupations are per se takings, for which just compensation is due. See, e.g., id. at $\$ 15.12$ and cases discussed therein.

68. E.g., Kaiser Aetna v. United States, 444 U.S. 164 (1979).

69. Loretto v. Teleprompter Manhattan CATV Corp., 458 U.S. 419, 435 (1982) (footnote omitted).

70. 458 U.S. 419 (1982).

71. Id. at $438 \mathrm{n} .16$. 


\section{E. FOURTH AMENDMENT SEARCH AND SEIZURE}

\section{Extensive, Thorough, Intrusive Inspections}

The CWC makes clear that the inspectors, during the "nonchallenge inspections," have the right of "unimpeded access to the inspection site." These "non-challenge inspections" involve sites in the chemical industry that are subject to on-site inspections on a regular basis. There is no need for a nation to issue a "challenge inspection"-based on a suspicion that the building may harbor chemical weapons ${ }^{72}$-in order for these facilities to be subjected to an inspection. The inspectors in these situation also have carte blanche in deciding which items can be inspected. $^{73}$ The inspectors can interview personnel at the sites, inspect all documents, take photographs, carry away samples, analyze the samples, and keep portions of all samples. ${ }^{74}$ There may be continuous monitoring.

When it comes to "challenge inspections," the CWC has similar carte blanche power in choosing the places for inspection. The inspection team must have "unimpeded access to the inspection site. The items to be inspected will be chosen by the inspectors." 76 The inspectors "shall have the right to inspect documentation and records they deem relevant to the conduct of their mission." They have the right to have samples taken. ${ }^{78}$ There is no evidentiary standard. There is no neutral magistrate. Indeed, the CWC authorizes the inspection team to use "more intrusive procedures only as it deems necessary." The inspection team polices itself. There is no probable cause; there is no oath; there is no search warrant describing with particularity the places to be searched or the things to be seized. The CWC inspection compares to the general, thorough, house-tohouse search that one might expect in wartime, in the midst of the theater of war, while looking for a spy.

72. CWC, Verification Annex, Part X, Challenge Inspections Pursuant to Art. IX, 41 (cited in note 6).

73. CWC, Art. VI; CWC, Verification Annex, Part II, General Rules of Verification, 945 (cited in note 6).

74. CWC, Verification Annex, Part II, General Rules of Verification, 19 46-58 (cited in note 6 ). The inspection team need only supply a warning of 24 hours before showing up at the point of entry. For the initial inspection, the warning is 72 hours.

75. CWC, Verification Annex, Part III, 19 10,17, 18 (cited in note 6).

76. CWC, Verification Annex, Part II, 945 (cited in note 6).

77. CWC, Verification Annex, Part II, 947 (cited in note 6).

78. CWC, Verification Annex, Part II, I 52 (cited in note 6).

79. CWC, Verification Annex, Part X, 945 (cited in note 6) (emphasis added). 
Compare the general search envisioned by the CWC with the Supreme Court's description of the requirements of the Fourth Amendment:

The requirement that warrants shall particularly describe the things to be seized makes general searches under them impossible and prevents the seizure of one thing under a warrant describing another. As to what is to be taken, nothing is left to the discretion of the officer executing the warrant. ${ }^{80}$

A major purpose of the Fourth Amendment was to prevent exactly that which the CWC authorizes: "general warrants," which grant government officials "sweeping power" to invade the premises of "merchants and businessmen" in order to "search at large for smuggled goods." ${ }^{, 1}$

2. The Three Main Arguments that May Justify Limiting the Application of the Fourth Amendment

There are three main arguments that proponents of the CWC embrace in an effort to avoid the constitutional problems arising from the CWC's authorization of extensive and intrusive searches, without criminal search warrants, the decision of a neutral magistrate, or probable cause.

\section{a. Foreign Affairs or National Security Power}

First, commentators have argued that the President's "national security powers" justify inroads on the Fourth Amendment. ${ }^{82}$ One treaty supporter actually states:

$[P] r e s i d e n t i a l$ national security powers might permit U.S. consent to highly innovative and informative OSI [i.e. On-Site In-

80. Marron v. United States, 275 U.S. 192, 196 (1927). Marron is a half century old, but since 1927 the Supreme Court has extended the application of the Fourth Amendment, not contracted it.

81. Marshall v. Barlow's, Inc., 436 U.S. 307, 311 (1978) (footnotes and citations omitted). The Court also noted: "The Warrant Clause of the Fourth Amendment protects commercial buildings as well as private homes." Id. at 311. Warrantless searches are "generally unreasonable," and "this rule applies to commercial premises as well as homes." Id. at 312.

[T] he Fourth Amendment's commands grew in large measure out of the colonists' experience with writs of assistance [which] granted sweeping power to customs officials and other agents of the King to search at large for smuggled goods.

United States v. Chadwick, 433 U.S. 1, 7-8 (1977).

82. E.g., Connolly, Arms Control Today at 8, 9 (cited in note 8). See also Benjamin Wittes, Aldrich Ames' Legal Legacy: Surveillance Court Gets New Powers, Legal Times 1, 22 (Nov. 7, 1994) (referring to Attorney General Reno's “inherent authority" justification of warrantless searches). 
spection], particularly of commercial facilities with lesser constitutional protection. ... Innovative, intrusive OSI of manufacturing, transportation, storage and $R \& D$ facilities could be invaluable tools for arms control. The Constitution is favorably disposed. ${ }^{83}$

This national security argument, frankly, is surprising. The people who are subject to the searches are neither foreign nationals nor agents of a foreign government; they are U.S. citizens living in the United States, not in the theater of war. Remember, when Attorney General John Mitchell tried to use national security to undercut the application of the Fourth Amendment, the Supreme Court was unpersuaded. ${ }^{84}$ It has never invoked the political question doctrine to avoid or to dismiss an individual's claim that the foreign affairs power violated a constitutional right. ${ }^{85}$

\section{b. Spending Power}

CWC supporters have also sought to rely on the Government's spending power. Basically, the line of reasoning is that companies who contract with the Government will "waive" their Fourth Amendment rights as a condition of doing business with the Government. ${ }^{86}$

If this argument is valid, one wonders the extent of its logic. Could tenants in a Government housing project be forced to "waive" their rights under the Fourth Amendment as a condition of receiving housing? $?^{87}$ Why stop with the Fourth Amendment? Could the Government require housing tenants to waive their rights against self incrimination under the Fifth Amendment, or their right to a jury trial in a criminal case? Could the

83. Connolly, Arms Control Today at 12 (cited in note 8) (emphasis added).

84. E.g., United States v. United States District Court, 407 U.S. 297 (1972); Zweibon v. Mitchell, 516 F.2d 594 (D.C. Cir. 1975), cert. denied, 425 U.S. 944 (1976). See also Powers, Secrecy and Power at 439-85 (cited in note 4).

85. Lewis Henkin, Foreign Affairs and the Constitution 486 n.6 (Foundation Press, 1972). See also David A. Koplow, Arms Control Inspection: Constitutional Restrictions on Treaty Verification in the United States, 63 N.Y.U. L. Rev. 229, 325-30 (1988).

86. E.g., Connolly, Arms Control Today at 8, 9 (cited in note 8).

87. The Clinton Administration, in fact, has argued that public housing tenants should be required to sign leases that would waive their Fourth Amendment rights and allow the police to search their apartments without warrants. Guy Gugliotta, Clinton Lets Police Raid Projects, Washington Post A1 (April 17, 1994). See also Clarence Page, For CHA Residents, a Fight to Keep Their Constitutional Rights, Chicago Tribune $\$ 1,21$ (April 13, 1994) (opposing Clinton plan); Editorial, Gun Sweeps: No Model for Cities, New York Times A18 (April 20, 1994) (opposing Clinton policy); Charles Ogletree and Abbe Smith, Clinton's Plan is Misguided, New York Times 23 (May 7, 1994) (opposing Clinton plan). 
Government force its contracting parties to waive their rights of free speech? The right against cruel and unusual punishment?

In none of these cases is there any true "waiver," because a waiver is a voluntary relinquishment of a known right. Instead the Government is conditioning benefits on the recipient giving up constitutional rights. The Court will not allow any such forced relinquishment or surrender of constitutional rights, as indicated in the leading case on this issue, South Dakota $v$. Dole. ${ }^{88}$ In that case Chief Justice Rehnquist, for the Court, upheld the power of Congress to withhold federal highway funds from states that allowed the purchase of liquor by people under 21 years of age. The Court used a four-part test to determine if conditions imposed are valid under the spending clause. First, the spending power must be in pursuit of the general welfare; second, Congress must speak "unambiguously" so that recipients of the funds exercise their choices knowingly; third, the condition must not be unrelated to federal interest in the particular national program; and fourth, there must not be an "independent constitutional bar" to the federal government's conditional grant of funds. ${ }^{89}$

Let us briefly focus on that fourth requirement, that there be no "independent constitutional bar" to the federal government's conditional grant of funds. In Dole, the Court found that the Twenty-first Amendment (dealing with state powers over alcohol) was not an independent constitutional bar. But, the Court said, Congress could not use its spending powers-

to induce the States to engage in activities that would themselves be unconstitutional. Thus, for example, a grant of federal funds conditioned on invidiously discriminatory state action or the infliction of cruel and unusual punishment would be an illegitimate exercise of the Congress' broad spending power. ${ }^{\text {so }}$

Congress, in short, could no more use its spending power to require its contracting parties to waive their rights under the Fourth Amendment than it could use its spending power to require its contracting parties to waive their rights under the Eighth Amendment, forbidding cruel and unusual punishment.

88. 483 U.S. 203 (1987).

89. Id. at 209.

90 . Id. at 210-11. 


\section{c. "Pervasively Regulated" Industries}

The last major argument is that Congress can dispense with the Fourth Amendment protections such as the requirement of a search warrant and probable cause, because the places to be searched are already "pervasively regulated" so that the requirements of the Fourth Amendment are inapplicable.

First, many of the places to be searched are not "pervasively regulated." My garage, for example is not pervasively regulated, but it is subject to be searched under the CWC. The Clorox Corporation is not pervasively regulated, but chlorine can be used to make poison gas. A soap manufacturer is not pervasively regulated, but the long arm of the CWC subjects the soap manufacturer to extensive searches without a warrant.

Second, whatever the meaning of "pervasively regulated," the Supreme Court has told us that it does not include the Dow Chemical Company. ${ }^{91}$ The Dow Chemical Company is an obvious target of the CWC-indeed, the United States has already said that the entire "private chemical industry of the United States is fully subject to the inspection provisions" of the CWC. ${ }^{92}$ But the Supreme Court has made it quite clear that the Fourth Amendment applies with full force to that company and others like it.

The Court has explained that a "closely regulated industry" is "the exception," not the rule. ${ }^{93}$ What distinguishes closely regulated enterprises from ordinary businesses "is a long tradition of close government supervision, of which any person who

91. Dow Chemical Co. v. United States, 476 U.S. 227 (1986). The Court (5 to 4) upheld aerial observation, within navigable airspace, by the EPA of open areas, a 2000acre tract. The majority made it clear that Dow did not have a "subjective expectation of being free from aerial surveillance since Dow had taken no precautions against such observation, in contrast to its elaborate ground-level precautions." 476 U.S. at 230 (emphasis added). The majority, id. at 237, acknowledged Donovan v. Dewey, 452 U.S. 594 (1981), the case referring to "pervasively regulated businesses, and explicitly stated:

Dow plainly has a reasonable, legitimate, and objective expectation of privacy within the interior of its covered buildings, and it is equally clear that expectation is one society is prepared to observe.

476 U.S. at 236 (emphasis added). The Court emphasized that the EPA engaged in only aerial observation, did not use "highly sophisticated surveillance equipment," and effectuated its observations "without physical entry." Id. at 237-38 (footnote omitted) (emphasis in original). Needless to say, the CWC contemplates physical entry of enclosed spaces, which would then be subject to extensive searches.

92. Statement of the U.S. Representative to the Conference on Disarmament: Chemical Weapons Convention-Compliance, July 19,1984, reprinted in Documents on Disarmament 531, 534 (1984) (cited in note 32).

93. Marshall v. Barlow's, Inc., 436 U.S. 307, 313-14 (1978). 
chooses to enter such a business must already be aware." ${ }^{\text {94 }}$ The Supreme Court has warned us that "pervasively regulated business(es)" - that is, liquor, firearms, and mining-are "responses to relatively unique circumstances." The "businessman in a regulated industry in effect consents to the restrictions placed upon him." ${ }^{.66}$ The CWC, in contrast, is not limited to pervasively regulated industries. It is not even limited to commercial buildings.

Donovan $v$. Dewey" is the leading case presenting the "pervasively regulated" rationale for removing the need for a criminal search warrant. The case upheld warrantless inspections of underground and surface mines. The Court noted that the "statute's inspection program, in terms of the certainty and regularity of its application, provides a constitutionally adequate substitute for a warrant." What commentators often miss about this decision is why the Court dispensed with the normal warrant requirement. The Donovan Court found it "difficult to see what additional protections a warrant requirement would provide" None of these factors apply to the CWC's intrusive inspections.

First, "the Act requires inspection of all mines and specifically defines the frequency of inspection." 100 The CWC will not provide for regular inspection of all places that could produce or store chemical weapons. Indeed, because the standard inspections (i.e., the inspections other than the challenge inspections) are tied to the quantity of specific chemicals produced, the eligibility of some facilities may be episodic. Moreover, challenge inspections may occur anywhere; they are not imposed solely at facilities capable of producing dual-use chemicals.

Second, the Mine Act provided that a mine operator could know the inspector's purpose and the limits of the inspection because "the standards with which a mine operator is required to comply are all specifically set forth in the Act or in Title 30 of the Code of Federal Regulations." ${ }^{101}$ Needless to say, the CWC does not provide specificity regarding the limits of the inspec-

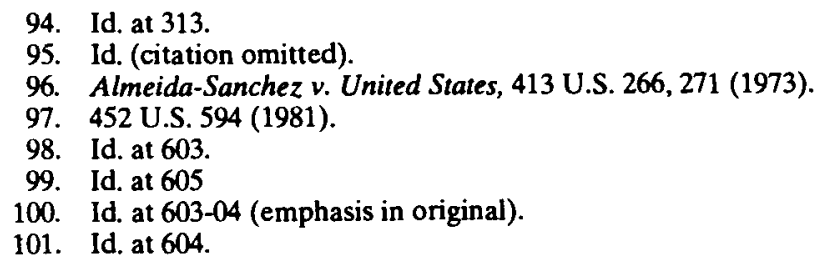


tion. On the contrary, it authorizes the inspector to look in every nook, niche, and cranny.

Third-and this is the most important limitation - "the Act provides a specific mechanism for accommodating any special privacy concerns that a specific mine operator might have." 102 If the mine operator refused entry (which he or she could legally do-unlike the regime of the CWC), the Secretary of Labor could not search the premises; instead, he could only commence a civil action to allow a search. This injunctive proceeding provided an adversary hearing in which a court could determine whether the search should proceed and, if it should, under what limits. ${ }^{103}$

When the law enforcement official seeks a search warrant, there is no adversary proceeding. The law enforcement official presents his case, ex parte, before the magistrate. The Dewey decision gave the mine operator more protection than she would have received in the case of a regular search warrant.

Another way of examining this issue is to ask whether the requirement of a warrant would benefit the mine operator more than the statutory scheme. ${ }^{104}$ The Dewey Court found that it would be "difficult to see what additional protection a warrant requirement would provide." 105 The warrant requirement (the ex parte proceeding) offers less protection than the statute, which provided an adversary hearing. ${ }^{106}$ The Dewey Court gave the mine inspector no right to bust in without a search warrant. Instead, the inspector could only ask permission to inspect. If the mine operator refused entry, the inspector had the burden of going to court and seeking an injunction. The Dewey decisioneven in the case of "pervasively regulated" industries-does not sanction the warrantless general search that the CWC contemplates.

There should be little doubt that the CWC has serious problems under the Fourth Amendment after Marshall v. Barlow's Inc. ${ }^{107}$ In that case the Court considered a provision of the

102. Id. at 604 .

103. Id. at 605 . See generally Wayne R. LaFave, 4 Search and Seizure: $A$ Treatise on the Fourth Amendment $\$ 10.2$ (b) at $408-08$ (West, 3d ed. 1996).

104. This analysis is developed more fully in LaFave, 4 Search and Seizure $\$ 10.2(\mathrm{~h})$ at $455-56$ (cited in note 103 ).

105. 452 U.S. at 605.

106. See LaFave, 4 Search and Seizure $\$ 10.2(\mathrm{~h})$ at $455-56$ (cited in note 103): "A warrant is clearly of no benefit" when a statute provides that there shall be an adversary hearing "in lieu of the ex parte application."

107. 436 U.S. 307 (1978). 
Occupational Safety and Health Act (OSHA) permitting inspectors - without any warrant-to:

enter without delay and at reasonable times any factory, plant, establishment, construction site, or other area, workplace or environment where work is performed by an employee of an employer ... to inspect and investigate during regular working hours and at other reasonable times, and within reasonable limits and in a reasonable manner, any such place of employment and all pertinent conditions, structures, machines, apparatus, devices, equipment, and materials therein, and to question privately any such employer, owner, operator, agent, or employee.

The searches that OSHA authorized were-unlike CWC searches-limited to business establishments. The statutory searches that OSHA authorized were-unlike CWC searcheslimited in scope and (as the statute kept emphasizing) "reasonable." Yet, the Supreme Court nevertheless held that this OSHA provision violated the Fourth Amendment.

The OSHA searches were unconstitutional without a search warrant, even though the Court admitted that OSHA regulates "a myriad of safety details that may be amenable to speedy alteration or disguise." 109 The searches of the CWC will be more intrusive and more extensive than the searches discussed in the Marshall case. If the OSHA searches were unconstitutional, then $a$ fortiori, the more extensive searches of the CWC must also violate the Constitution.

\section{The CWC and the Protections of American Constitutional Law}

The Fourth Amendment, unlike the just compensation clause, is not cured by the mere payment of money. The exclusionary rule, monetary damages, and injunctions are three of the remedies that the courts have created to protect the rights secured by the Fourth Amendment. The first two remedies do not cure the violation - they merely seek to provide some sort of remedy. An injunction, on the other hand, is an effective remedy that is designed to prevent the violation. That is why proponents of the CWC have urged Congress to take away from the

108. 29 U.S.C.A. $\$ 657$ (a) (emphasis added).

109. 436 U.S. at 316. 
judiciary its power to issue injunctions of unconstitutional searches authorized by the CWC. .10 $^{10}$

If Congress seeks to limit the powers of courts to implement the guarantee of the Fourth Amendment, the courts will most likely invalidate this restriction, ${ }^{111}$ and then hold that some or all of the CWC is unconstitutional. Then the United States will be in violation of international law. A treaty, as Chief Justice Marshall noted long ago, is a contract between two or more nations. ${ }^{112}$ If we breach this contract, we are violating international law, even though the breach is required by our domestic law, that is, by our Constitution. In addition, if the United States does not comply with all of the CWC terms, the CWC provides for sanctions.

We should not be dumbfounded if foreign adversaries (who often do not respect our basic legal principles such as probable cause, search warrants, intellectual property, and just compensation) castigate America's refusal to follow international law, using these court challenges for political propaganda, claiming that the judicial response of American courts demonstrates that the United States does not really support the elimination of chemical weapons. Moreover, other countries may use their own constitutions to justify and excuse their refusal to comply with the CWC.

The CWC gives only a very limited recognition to these problems and does not provide for a constitutional defense against an effort to impose sanctions, or a defense of a charge of violating international law. Article VII recognizes that each state's obligations to enact legislation must be "in accordance with its constitutional processes." 114 However, this requirement, read in context, only means that the United States must follow its normal procedures to enact legislation (an affirmative vote of both Houses of Congress plus the Presidential signature or an override of a veto). Unfortunately, Article VII of the CWC does not excuse the United States from enacting the necessary legislation merely because the legislation would violate our own Constitution.

110. Kellman and Tanzman, Implementing the Chemical Weapons Convention at 16 (cited in note 4).

111. For a complete discussion, see Rotunda and Nowak, 1 Treatise on Constitutional Law: Substance and Procedure $\$ 2.10,2.11$ (cited in note 4).

112 Foster $v$. Neilson, 27 U.S. (2 Pet.) 253, 314 (1829). See also Head Money Cases, 112 U.S. 580, 598 (1884).

113. CWC, Art. XII, 91 . See also id. at 99 2-4 (cited in note 6).

114. CWC, Art. VII, 91 (cited in note 6). 
Part X of the Verification Annex includes an unusual paragraph. Part X deals with challenge inspections pursuant to Article IX and inspections of perimeters. Paragraph 41 provides that the inspected State - in providing access to a perimeter area specified in paragraph 38-must allow the inspectors "the greatest degree of access taking into account any constitutional obligations it may have with regard to proprietary rights or searches and seizures." 115

This provision may have been drafted to give comfort, but it is troubling. First, it only applies to searches under paragraph 38. The negative pregnant of this statement is that constitutional obligations do not apply in other circumstances.

Second, the last sentence of this paragraph 41 undercuts the narrow protection afforded earlier when it states:

The provisions in this paragraph may not be invoked by the inspected State Party to conceal evasion of its obligations not to engage in activities prohibited under this Convention. ${ }^{116}$

Only the United States, not a private individual, can invoke this paragraph, because only the United States is the "inspected State Party."

Moreover, although the United States can raise an objection to searches under paragraph 38 , it is asked to promise solemnly that it will not raise any constitutional objections (the "constitutional obligation," this paragraph provides, "may not be invoked") for an improper purpose. But that restrictionwhich limits the right of the United States to follow its own Constitution-assumes the point in dispute; the inspectors cannot determine if the United States is raising objections for an improper purpose unless the inspectors can inspect. The chilling effect of this paragraph cabins the protections of the Fourth Amendment, treats them as troublesome technicalities that private parties cannot raise at all, and requires the United States to agree that it will not raise objections except in rare circumstances.

\section{NO RESERVATIONS ALLOWED}

In the past, it was quite common for the U.S. Senate to avoid constitutional problems by ratifying a treaty subject to various "reservations." The Senate, when ratifying the CWC,

115. CWC, Verification Annex, Part X, 941 (cited in note 6).

116. CWC, Verification Annex, Part X, 941 (cited in note 6) (emphasis added). 
purported to enact various reservations. However, the CWC precludes this alternative. It provides explicitly that " $[\mathrm{t}] \mathrm{he}$ Articles of this Convention shall not be subject to reservations." Hence, no reservations are allowed by the CWC, even if the reservations are necessary in order to comply with our domestic law, including U.S. Constitutional Law.

This provision is very significant and highly unusual. Because the United States has now ratified the CWC, if it enacts legislation contrary to the $\mathrm{CWC}$, it will be violating international law. If the United States reserves this clause (makes a reservation to the no reservations clause) it will also be violating the CWC, because the CWC plainly allows no reservations. Nonetheless, Congress must respect our Constitution and, at the very minimum, should authorize no searches under the CWC unless the inspectors first obtain a search warrant, from a neutral magistrate, upon probable cause supported by oath or affirmation, describing with particularity the places to be searched and the things to be seized. Congress should also create a reasonable procedure to provide just compensation if any intellectual property is improperly taken because of a CWC inspection.

\section{CONCLUSION}

We all wish that poison gas and other chemical weapons had never been invented, but that genie is out of the bottle. The Chemical Weapons Convention, unfortunately, will not fulfill its promise of wiping these weapons from the face of the earth, but it may give us a false sense of security and lull us into thinking that a serious problem has found a solution. Equally unfortunate is the fact that the CWC will authorize intrusive inspections of thousands of private facilities, businesses and homes, resulting in the violation of the Fourth Amendment and the taking of intellectual property (for which this country must provide just compensation).

117. CWC, Art. XXII, at 45 (cited in note 6). To leave no room for any doubt, this clause goes on to say, "The Annexes of this Convention shall not be subject to reservations incompatible with its object and purpose." Id. Hence, there can be no material reservation to any of the Annexes to the CWC. 